\title{
Developing strategies to promote the Iranian international film market
}

\author{
Mahmood Mohammadian ${ }^{\text {a }}$ Amir Hassan Nedaei ${ }^{\mathbf{b}}$, and Yasaman Giyahi ${ }^{{ }^{*}}$
}

${ }^{a}$ Faculty of Management and Accounting, Allameh Tabataba'i University, Tehran, Iran

${ }^{b}$ Faculty of Art, Tarbiat Modares University, Tehran, Iran

\begin{tabular}{l}
\hline A R T I C L E I N F O \\
\hline Article history: \\
Received August 26, 2011 \\
Received in Revised form \\
November, 11, 2011 \\
Accepted 18 November 2011 \\
Available online \\
22 November 2011 \\
\hline Keywords: \\
Iranian film market (IFM) \\
Film market \\
Film marketing mix \\
Film marketing model
\end{tabular}

\section{A B S T R A C T}

\begin{abstract}
International film market of Iran (IFM) is one of the most important presenters of different films and television programs to be sold in the world market especially in Middle East. The primary purpose of this paper is to investigate different methods to promote this market. The study uses a questionnaire and distributes it among buyers and sales agents of IFM. The results of hypothetic tests prove that the socio-cultural factors are the most important reasons for the participants. Another important criterion promoting sales of movies is different awards from various movie festivals dedicated to moviemakers. The opening date and place of market, publication and publicity are other important criteria influencing sales of movies. The paper illustrates film-marketing mix for film marketers. Indicators, which are important for participants in international film festivals, are also illustrated for international film market holders.
\end{abstract}

\section{Introduction}

Cinema, as the $7^{\text {th }}$, art has got a special place among different societies of many countries with its socio-cultural, economical and even political impacts, which cannot be denied (Goldbaltt, 2002; Cleve, 2006; Marich, 2009). Film plays an essential role in this society and economy of countries. The culture has a direct impact on the policies of a society and followed technological progressions of economy such as copyright laws, which supports the film business. The global market relies on the economical, cultural and political properties of a film and its production (Skinner \& Rukavina, 2003; Greenwald \& Landry ,2009).

Annually, various film festivals are held in many countries, among the very events, the award ceremonies and film markets are of high importance for their media feedback from all over the world (Rutherford Silvers, 2004). At the end of 80's, about 300 festivals and markets were held all over the world, which nowadays the numbers of events have reached to 13,000 in more than 80 countries per

* Corresponding author. Tel: + 989123764259

E-mail addresses: ysmn.giahi@gmail.com (Y. Giahi)

(C) 2012 Growing Science Ltd. All rights reserved. doi: 10.5267/j.msl.2011.11.010 
year. Entertainment is one of the first sources of income in many countries such as United States and producing and presenting media programs include a significant portion of the investment (Kotler \& Armstrong, 2008; Yager \& Yager, 2009; Thompson \& Bordwell, 2010). We intend to present a test plan for film marketing at international film festivals (IFM) held in Tehran/Iran since it is one of the most famous and the biggest markets for exhibiting the movies. Squire (2006) defines film market as a place to do business but not for public audiences and it can be a part of a festival (e.g. Cannes Film Market). Sometimes it is held independently such as American film market (AFM) (Yeoman et al., 2004). In this way, the local filmmakers will find new opportunities with various facilities at a place in which buyers and sellers get together from all over the world.

Kerrigan (2010) emphasizes that film markets are special events for the film sellers and distributors to deal with international distributors. Film marketing refers to any activity, which helps a film survives for its audiences before getting expired (Greenwald \& Landry, 2009). IFM is held each year in February in Tehran simultaneously with another domestic international festival called Fajr. To promote IFM, we have to identify effective factors on the film market and its marketing such as film credits, casting, genre, theme, audiences (the age classification) and its distribution.

Nowadays, there are varieties of festivals more than what we had in the past and film marketing requires more improvements and creativity. In other words, a marketer should be aware of how to apply useful and effective factors in his/her job apart from the theme, genre and stars of the film just like what is required in IFM, which is a reasonable management in addition to its finance and income (Hoyle, 2002). There are two primary objectives for having Farabi film festival, which are as follows,

1. to present a solution for more impressive participation of the companies and independent people at IFM,

2. and to present a useful solution to promote the sales of the Iranian films at IFM.

The film marketers always check the demand for their products through the feedback they receive from the audiences. A festival or a market must ensure the audiences and attendees that any event has the right capability to cover all relative expenses. For pricing, a marketer should know about the policy of other competitors as his/her business partner and check all the details in this case (Hoyle, 2002).

The primary objective of this paper is to determine important factors influencing film festival. The study of this paper first presents the necessary relative questions associated with the hypothesis of the paper in section 2. Section 3 presents details of the finding and concluding remarks are given in the last to summarize the contribution of the paper.

\section{The proposed study}

The proposed study of this paper investigates the most important factors influencing people to participate film market, buying and selling films. There are five main questions associated with our objectives, which are as follows,

1. What is the most important motive participants have in an international film market in terms of different aspects such as economical, socio-cultural, political, legal, and technological, etc. ?

2. What is the most effective factor on film marketing mix?

3. What is the factor mostly affect the price of a film?

4. What is the factor mostly affect the marketplace?

5. What is the most important factor in making a film?

6. What is the most important factor in promotion? 
Based on the above questions, we have established the following six hypothesis,

H1: Economical motive is the most important participants' motive in IFM.

H2: Film is the most effective factor on film marketing mix.

H3: Film awards is the factor mostly affect the price of a film.

H4: Market date is the factor mostly affects the marketplace.

H5: Genre is the most important factor in making a film.

H6: Answering and continual communications of the market secretariat is the most important factor in promoting films.

\section{Research methodology}

\subsection{Data collection}

Many useful sources have been applied in this research. The initial resources have been prepared based on the questionnaires with very exact statistics. The second sources are like internet, books, articles, reviews and interviews. There are 83 questions and each of the variables and indexes have been designed as a theoretical model by using 5 item Likert spectrum. The questions are about the factors influencing the film markets and the film itself.

There are four questions about the environmental factors, four about the marketing elements and eight questions about the film price. The other four questions are associated with the market place to promote the film, ten questions are related to film as a product and there are fifty questions about film distributors. Cronbach alpha ratio has been calculated as 0.961 , which means the questionnaire is consistent.

\subsection{Data analysis}

The results of the questionnaire are analyzed based on Kolmogorov-Smirnov, Wilckokson and Friedman tests. We have used the following formula to calculate the minimum number of sample size (Krejcie \& Morgan, 1970),

$n=\frac{N \times z_{\alpha / 2}^{2} \times p \times q}{\varepsilon^{2} \times(N-1)+z_{\alpha / 2}^{2} \times p \times q}$,

where $N$ is the population size, $p=1-q$ represents the yes/no categories, $z_{\alpha / 2}$ is CDF of normal distribution and finally $\varepsilon$ is the error term. Since we have $p=0.5, z_{\alpha / 2}=1.96, \varepsilon=0.05$ and $N=251$, the number of sample size is calculated as $n=153$. Fig. 1 shows details of our survey.

\subsection{Results and discussions}

The data analyses in the modified statistical showed that \%30.9 of the repliers are women and \%67.8 of them are men.

H1: Economical motive: Economical motive is the most important one at international film market. The result (2.6) was unfortunately undesirable and was the second alternative for the participants. However, the social cultural ones (3.46) were actually acceptable. The political and legal (1.66) and technological motive (2.26) are of no importance according to the participants’ POV.

H2: The Film: The product (film) is the most important one in its marketing. Among four marketing mix, the film, itself (2.99) is very significant in participants' opinion. Then the film promotion process (2.52), price (2.32) and the place (2.16). Consequently, all four elements are effective and considerable as well. 
H3: Film Awards: Film award is the factor mostly affects the price of a film. Among the 8 identified factors on the price, we can consider the received awards as a criterion (4.93). The right of film (4.7) and its sales territory (4.66) and the film screening records (4.64), the film market regulation (4.57), the film stars (4.43), the sales validity of its copyright (4.08) and film production year (4) are as the second to $8^{\text {th }}$ alternative.

H4: Date of market: Market date is the factor mostly affects the marketplace. Among the 5 indexes identified so effective on the variable of place, the market's data seems to be important at IFM (3.91). Therefore, it is considered as the first alternative and the marketplace (3.72), and its duration (3.31) among the 5 indexes and based on IFM participants. They get the second and third position. Markets at the same time (2.08) and markets in the same place (1.98) cannot be counted much important at IFM).

H5: Genre: It is not mostly agreed among 6 indexes concerning the film itself. IFM participants believe that the film production technique (4.02) is in the first place and then they vote for its genre (3.85), the second one and the credits and casts (3.74), stars (3.62), film's running time (3.01) and age classification (2.75) as the $3^{\text {rd }}$ to $6^{\text {th }}$ places. The results concerning co production from emphasizes on the four co production models and the project (2.88), screenplay (2.69), financing as the semifinished projects (2.3) and the plot (2.13) are in $1^{\text {st }}$ to $4^{\text {th }}$ alternatives.

H6: Answering and continual communications of the market secretariat: Among the 8 indexes modified and identified and modified for publicities and public relation affairs, IFM participants accepts communications by the market secretariat office is in the first place (5.46). The services by public relations and media (5.18), services by market organizers (5.09), film adverts by market (4.6) and market publicities (4.52), all is in the second to $5^{\text {th }}$ place. For IFM participants, market's website (3.84) marketing sponsoring for the awarded films (3.71) and holding workshops (3.6) are not important for the repliers.

The data analysis indicate that there are other indexes, which are part of the public relations task like inviting special guests (3.88), notifications during the market (3.86), the reflections before and after it (3.59), inviting international press agents (3.52), call for entries for the next edition (3.2), but except the above ones, the press conference is not the important index (2.95). Market guides and stands (2.18), catalogues (who is where?) (1.98), stands and their equipments (1.84).

There are multimedia (2.19) and word of mouth (2.04) seem to be more effective to IFM participants but not the gifts (1.77). The film review reflection in domestic and foreign publications (1.52) and media (1.48) seem to be very considerable as the first and second alternatives. Screening films (5.49), adverts in technical publications (4.77), posters (4.68), film announces (4.68) at the market publicities on TV channels (4.34), billboards (4.13), banners (4.09), market's bulletin (3.9) are in the $1^{\text {st }}$ to $8^{\text {th }}$ alternatives in publicities agencies services.

There are 6 indexes out of the 7 ones, including posters (4.64), brochures (4.42), oral publicities (4.36) multimedia (4.27), TV channels (3.9 9), press book (3.79) are in the $1^{\text {st }}$ to $7^{\text {th }}$ alternatives in advertising by the film sales agency. The film (2.47), the way a manager present a film in the market (1.84) and the sales company (1.69) are in the $1^{\text {st }}$ to $3^{\text {rd }}$ place. What IFM participants consider significantly is the quality and level of production according to the global standards (2.58), dubbing and subtitling in some languages (2.03), packing (1.83) are $\mathrm{n}$ the $1^{\text {st }}$ to $3^{\text {rd }}$ place. IFM participants in each edition (2.06), demo for productions (2) and the presentations impact on the commercial materials (1.94) in the $1^{\text {st }}$ to $3^{\text {rd }}$ place. Famous sales companies, their products and profile (2.15), their participation records at different film markets (1.96) and IFM market (1.89) in the $1^{\text {st }}$ to $3^{\text {rd }}$ place. 


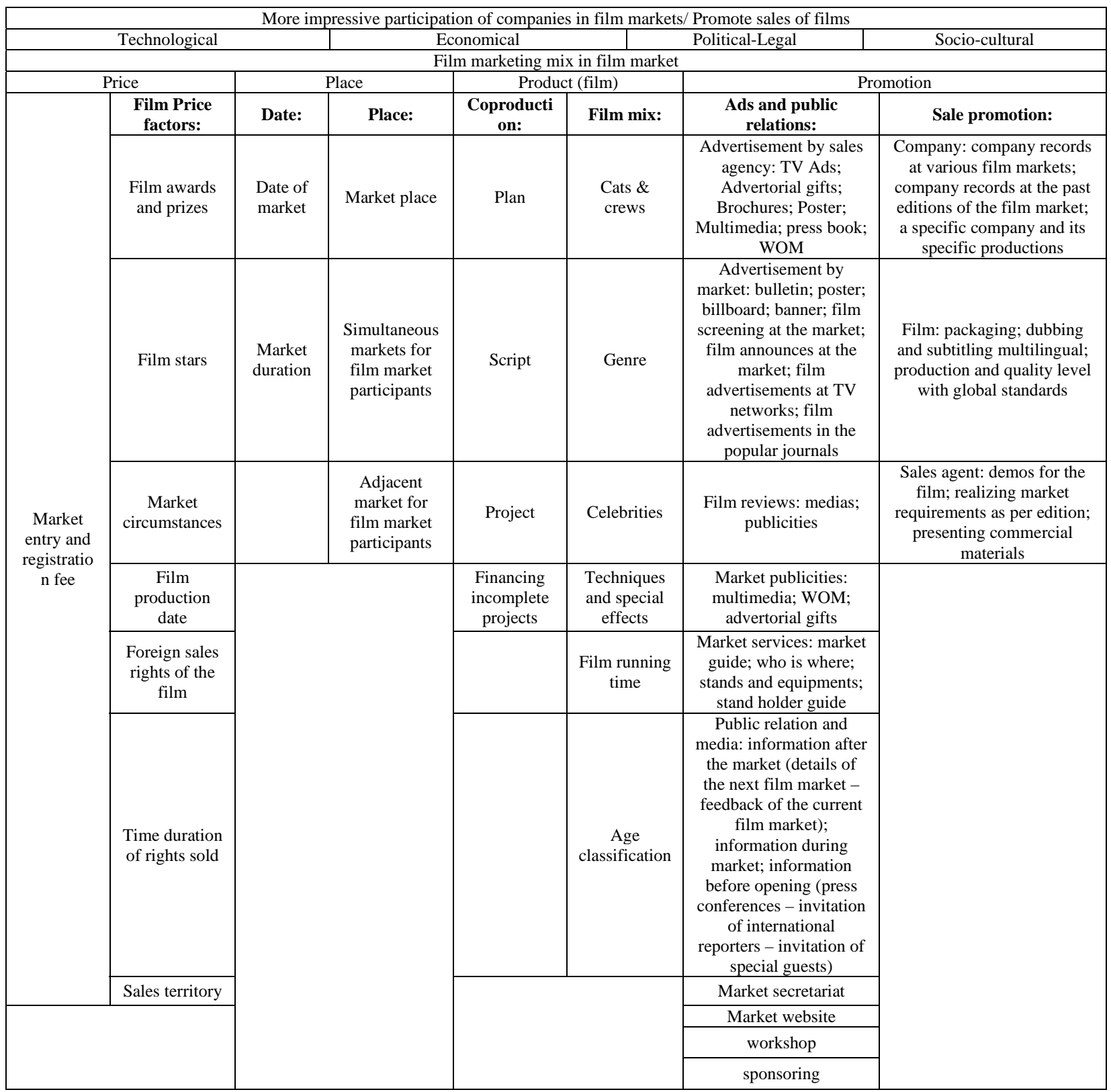

Fig. 1. Details of the survey

\subsection{Other Findings}

We face with the same and indifferent priorities concerning the factors of place, sales options, film selections and services given to the participants. The opening date, the place and duration of the market holding are the ranked priority of 1-3. The sales options, the film itself, sales agent and company, the production quality, dubbing, subtitling and packing are all considered as $1^{\text {st }}$ and $3^{\text {rd }}$ ranking priority. "Who Is Where?" catalogues, stand holders and the market guide as the market services are also of 1-3 ranking importance. While the Iranian film marketing experts believe the sales agent and company as the important factors (1-3) of ranking priority, the foreign ones think differently in this regard and they consider them of the same importance.

The sales agent has to know about the requirements of each market edition, the requirements of each market edition and present a demo for the productions and related skills to publicize the materials as 
1-3 ranking. The results emphasize on the Iranian and foreign view on marketing of the same importance. Nevertheless, among other influencing factors, their priority in each group, the views are absolutely differed and comparable (the above scheme). The motive for attending at the market, the economical-cultural factors are of the first rank while the Iranian marketing experts believe the technological, economical, legal-political are orderly of 1-4 ranking and for the international ones, they are considered 2-4.

The film itself, for the both groups on production has the first priority and the sales place is the fourth one. It is worth to mention that the price is of high importance but comes as the $2^{\text {nd }}$ rank. For the nonIranians, the price is the main reason for the film genre, its credits, cast and production techniques and publicities. Concerning the price factor, both groups have common idea for the film screening records, which is ranked 4. Iranian film marketers believe the price as the awards, market conditions, superstars, screening records, sales territory, sales right's period while foreign marketers consider the mentioned factors in 1-8 ranking priority. This difference shows they are not common at the time of film distribution and sales reasonable quotations.

Therefore, having considered the above 8 specifications into some regards, we can have better chance and opportunity to sell and distribute a film. For example, the score of the foreign experts' attention is on the rights of the film but for the Iranians, it is just the award, which is of the third rank for them. Now, the sales agent can decide to maneuver for the better price for the film in abroad. Re coproduction, the screenplay project, plot and the investment on semi-finished projects are important but the foreign ones are against the point.

Re film, except the factors of its running time and age classification, which are in the fifth and sixth rank, their view is actually different. The film production techniques, casting, genre are of $1^{\text {st }}-4^{\text {th }}$ rank while genre, credits and production techniques are considerable for non-Iranian experts.

Re publicity and film public relation affairs except markets' publications, both ones give the ranking priority for 4 of all and this differs from the other 7 factors. Iranian film marketers believe that the publicity done by the market secretariat office, their managing queries, film market public relation office, market services, its website and sponsoring and workshop are orderly on the top ranking. However, the foreign film marketers, the order differs. Market services, film market public relation notifying the applicant, the market secretariat of office, market advertisements, its website and sponsoring and workshops are in order for ranking priority.

Re market notifications except the opening press conference of the market and next edition's call for entry, both groups consider them as 5 and 6 rankings. The Iranian experts, inviting special guests, notifications during the market's days, the international press agents and market feedbacks are of $1^{\text {st }}$ to 4th ranking priority. While the international ones, market's feedback and inviting international press agents have had the same priority in ranking. Re the kinds of publicities, except screening film as ( $1^{\text {st }}$ rank) and billboard ( $6^{\text {th }}$ rank) are common for the both groups.

Screening films at market, its advertising in technical publications, film announcements at market, film publicities on TV channels, posters, billboards, banner and market bulletin have got 1-8 ranking priority. This recent ranking helps the Iranian sales copyright recognize the points considered as publicity tools by the non-Iranian experts and apply those with the priority to publicize their own film. At the same, the foreign markets get informed of the film publicity tools applied to sell their production to the Iranian sellers.

What the sellers do to publicize, except those of multimedia, are considered as the $4^{\text {th }}$ ranking and gifts $\left(7^{\text {th }}\right.$ rank) are common between the 2 groups. The Iranian experts give 1-7 ranking priority to the film posters, its publicity on TV networks, brochures, multimedia, word of mouth publicities, press 
book and gifts while it is different from what the foreign ones believe as oral publicities, brochure, poster, multimedia, press book film publicities on TV networks and gift are orderly of 1-7 ranking. The present discussed article refers to the indexes comparison for the active participants as international sellers and buyers, which give the required assistance to the Iranian market to get more familiar with those of the non-Iranian for better action and decision in near future carefully as possible.

\subsection{Implication of findings}

Based on the results of data analysis, followings are some suggestions for Farabi Cinema Foundation and other organization in charge of IFM.

- General factors impact on the research: Socio-cultural motive for IFM market participant being the first; the market provides an opportunity to get more familiar with the Iranian culture.

- About IFM date: Fajr International Film Festival is a prestigious festival and the market responsible cannot change the festival's opening date. Since IFM is held on date between Rotterdam and Berlin international film festival as the important and famous ones. More people must be encouraged to participate in IFM.

- Film Co Production: All 4 types of co productions have been approved. Market provides the right chances for co producing films.

- Market secretariat: Public relation office of the festival and market secretariat can provide those interested in receiving information about the films.

- Inviting special guests: Festivals' and markets' managers are invited to IFM and all their costs (hotel and accommodations).

- Notifications while the market is being held.

- Market news feedback,

- Stand holders' guidebook,

- Film publicity by the market facilities for: Screening films at the market screen halls to advertise in the market's publications, film posters in the market for the companies participated, screening announces of the films even those on TV channels. In addition, there are TV channels from all over the world broadcast the festival news and cover all the press services in this regard. In this way, apart from the services, there is an income for the market holders.

For sales companies, the following are some of the necessary steps used to promote IFM,

- A poster is the most important mean of film publicity by the sellers. Skilled and technical designers are recommended to design the Iranian film posters.

- While designing the publicity materials, awards and screening background must be included production techniques based on global standards.

- Modern techniques and equipments must be applied to make films.

- Dubbing and subtitles in different languages: Films together with their subtitles or dubbing in the language of the buyer's country, will make a noticeable rise in the price for sale. 
- Sales companies at market: Film sales companies must present a reasonable profile about their field of activities.

\section{Conclusion}

In this paper, we have presented an empirical study to investigate important factors for international film market. The study designed a questionnaire and distributed among various people who were involved in international film market of Iran.. There were six hypothesis associated with the proposed study, which examine different aspects of film from economical and date of the movies to awards and the impact of all important factors to increase the sales and audiences have been discussed in details. The results generally indicate that Socio-cultural motive for IFM market participant is the first most important factors and the market must provide an opportunity to become more familiar with the Iranian culture. Since there is not much control on the date of market, people must be encouraged to participate in this market through different advertising.

\section{Acknowledgment}

The authors would like to put on record their appreciation for the two anonymous referees and the Editor for their valuable suggestions, which has significantly improved the quality of the paper.

\section{References}

Cleve, B. (2006). Film production management. $3^{\text {th }}$ ed., Focal Press. UK.

Greenwald, S. R. \& Landry, P. (2009). The business of film. Lone Eagle. USA.

Goldbaltt, J. (2002). Special Events. $3^{\text {th }}$ ed., John Wiley. New York.

Hoyle, L. H. (2002). Event marketing: how to successfully promote events, festivals, conventions, and expositions. Wiley. NewYork.

Kerrigan, F. (2010). Film marketing. Elsevier Butterworth-Heinemann. UK.

Kotler, Ph. \& Armstrong, G. (2008). Principles of marketing. $12^{\text {th }}$ ed. Pearson Education. USA.

Krejcie, R. V. \& Morgan, D. W. (1970). Determining sample size for research activities. Educational and Psychological Measurement. 30, 607-610.

Lieberman, Al \& Esgate, P. (2002). The entertainment revolution: bringing the moguls, the media \& the magic to the world. Financial Times/Prientice Hall. New Jersey.

Marich, R. (2009). Marketing to moviegoers: a handbook of strategies and tactics. $2^{\text {nd }}$ ed., Southern Illinois University Press. USA.

Rutherford Silvers, J. (2004). Professional event coordination. John Wiley. Canada.

Skinner, B. E. \& Rukavina, V. (2003). Event sponsorship. John Wiley. Canada.

Squire, J. E. (2006). The movie business book (3th). Simon \& Schuster. USA.

Thompson, K. \& Bordwell, D. (2010). Film history: An introduction, $3^{\text {rd }}$ ed. McGraw Hill international edition. Singapore.

Yager, F. \& Yager, J. (2009). Career opportunities in film industry. $2^{\text {nd }}$ ed, Ferguson. New York.

Yeoman, L. \& Robertson, M. \& Ali-Knight, J. \& Drummand, S. \& McMahon Beattie, U. (2004). Festival and events management: An international arts and culture perspective. Elsevier Butterworth-Hienemann. Oxford. 